\title{
POÉTICAS CONTEMPÔRANEAS: LIRISMO, COLETIVIDADE E RESISTÊNCIA NA POESIA DO RAP
}

\section{CONTEMPORARY POETICS: LIRISM, COLLECTIVITY AND RESISTANCE IN RAP POETRY}

Cleber José de Oliveira ${ }^{1}$

Recebido em: 29 ago. 2018

Aceito em: 12 jan. 2019

DOI 10.26512/aguaviva.v4i1.22166

RESUMO: O presente texto discuti o gênero rap sob a perspectiva de poesia líricocoletiva de resistência. Mais especificamente, levanta a seguinte hipótese, a saber: embora lírica a poesia do rap nacional apresenta um caráter coletivo, periférico e de resistência em sua composição. Sustenta isso, na medida em que é possível entrever uma espécie de transição do eu lírico do rap, que a priori é um eu-individual, para um eu-nós essencialmente coletivo; e é nesse empenho de buscar (com)unidade que reside o seu caráter de resistência. Sustenta ainda que tal poesia atua como instrumento de propagação e valorização das identidades, dos saberes, dos ritos, dos modos de vida e visões de mundo das comunidades que a produz. Isso também firma um lócus de enunciação que tem na periferia o seu próprio centro, referenciando assim a ideia de comunidade. Para tanto, analisa algumas letras de rap a partir de instrumentos teóricos da ciência linguístico-literária.

Palavras-chave: Rap nacional; Poesia lírica; Coletividade; Resistência.

ABSTRACT: The present text discussed the rap genre from the perspective of lyricalcollective resistance poetry. More specifically, it raises the following hypothesis, namely: although lyrical the poetry of national rap presents a collective, peripheral and resistance character in its composition. He maintains this, insofar as it is possible to envisage a kind of transition from the lyrical I of rap, which a priori is an individualego, to an essentially collective I-us; and it is in this endeavor to seek (with) unity that resides its character of resistance. He further maintains that such poetry acts as an instrument for the propagation and appreciation of identities, knowledge, rituals, ways of life and worldviews of the communities that produce it. This also establishes a locus of enunciation that has on the periphery its own center, thus referencing the idea of community. To do so, it analyzes some rap lyrics from theoretical instruments of linguistic-literary science.

Keywords: National Rap; Poetry lyrical; Collectivity; Resistance.

1 Universidade Estadual do Mato Grosso do Sul (UEMS) e Doutorando em Literatura na Universidade de Brasília (PósLIT/UnB). E-mail: cleber101578@gmail.com 


\title{
O EU-NÓS DO RAP NACIONAL
}

$\mathrm{Na}$ poesia do rap - falar de si é falar do/ao outro. Entendendo com T. S. Eliot (1972) a poesia manifesta-se a partir de três vozes. Segundo o autor a primeira voz da poesia em si já é a voz que manifesta o eu privado, o que se expressa para si mesmo ou no máximo para outra pessoa em particular. $\mathrm{O}$ mesmo autor afirma ainda que a poesia pode se manifestar por meio de mais outras duas vozes:

\begin{abstract}
A primeira voz é a voz do poeta que fala consigo mesmo - ou com ninguém. A segunda voz é a voz do poeta ao dirigir-se a uma plateia, seja grande, seja pequena. A terceira é a voz do poeta quando tenta criar uma personagem dramática que fala em verso, quanto está dizendo, não o que diria à sua própria pessoa, mas apenas o que pode dizer dentro dos limites de uma personagem imaginária que se dirige a uma outra personagem imaginária (ELIOT, 1972, p. 123-124).
\end{abstract}

Como se vê, a enunciação na poesia lírica (a primeira voz) se dá por meio de um "diálogo" do eu lírico consigo mesmo, que tem condições de inventar e usar códigos para si mesmo. Diferentemente, as outras formas de poesia (a de segunda e terceira vozes) pressupõem interlocutores e, portanto, códigos comuns compartilhados por esses interlocutores a um determinado grupo social com quem ele dialoga. Nesse sentido, pensando sobre a poesia do rap é possível afirmar que ela apresenta essas vozes, já que ao falar de si fala também do/ao outro, mas também oscila para as outras duas conforme a intenção de seu produtor - o MC.

De fato, o emissor inserido num grupo social qualquer "não é um Adão bíblico, só relacionado com objetos virgens ainda não nomeados" como apontou Bakhtin (2003, p.300). Parece ser este o caso do poeta que tem que falar com outrem (o de segunda voz e o de terceira voz) - ele usa códigos compartilhados pelos membros deste grupo. Diferentemente, o poeta de primeira voz (o lírico), se levado ao limite de suas potencialidades, seria esse Adão sozinho no paraíso, falando consigo mesmo, encarregado de inventar seus próprios códigos para definir o seu mundo e seus sentimentos.

No rap, esse processo também se manifesta e é de extrema relevância para manutenção da ideologia que é vinculada em seu discurso, pois geralmente esse discurso está pautado na primeira voz, porém são audíveis nesse mesmo discurso outras 
vozes. Podemos entender isso como sendo uma espécie de tensão, que até certo ponto é comum, no rap, pois apesar de seu discurso estar centralizado no eu, o mesmo se esforça para trazer o "nós" para a arena discursiva, traz ao mesmo tempo um "eu- individual" e um "eu-coletivo":

Amo minha raça, luto pela cor,

O que quer que eu faça é por nós, por amor

Não entende o que eu sou, não entende o que eu faço

Não entende a dor e as lágrimas do palhaço

E a minha mãe diz:

"- Paulo acorda, pensa no futuro que isso é ilusão, os próprio preto não tá nem aí com isso não, olha o tanto que eu sofri, que eu sou, o que eu fui".

(RACIONAIS MCs, 2002)

A gente vive se matando irmão, por quê?

Não me olhe assim, eu sou igual a você

Descanse o seu gatilho, descanse o seu gatilho

Meu rap é o trilho

Pra todas as famílias, aí,

Que perderam pessoas importante (morô meu)

Não se acostume com esse cotidiano violento,

Que essa não é a sua vida,

Essa não é a minha vida (morô mano!)

Procure a sua paz

(RACIONAIS MCs, 1998)

Esses fragmentos explicitam a tensão que se desenvolve na esfera líricodiscursiva do rap. $\mathrm{O}$ eu lírico se esforça para banir uma espécie de estranhamento entre ele e seus pares. Explicita ainda sua angústia entre defender a si e o outro, mas não ser compreendido nisso. Agregada nessa angústia há uma crítica contundente em relação as atitudes de alguns "irmãos" que se posicionam de modo contrário e até mesmo violento com seus pares, vide grifos. Ao mesmo tempo em que fala de si para si mesmo, busca também falar ao outro. Nesse sentido, o eu-individual transita para um "eu-coletivo", na medida em que se esforça para convencer seu "irmão" a mudar seu ponto de vista sobre a realidade. Faz isso não com atitudes violentas, mas sim com uma espécie de crença no poder da palavra. A mensagem de reflexão consciente que o eu lírico lança para o outro pressupõe uma tentativa de se criar um elo, uma ligação entre ambos por meio da palavra, pois

toda palavra serve de expressão a um em relação ao outro. Através da palavra, defino-me em relação ao outro, isto é, em última análise, em 
relação à coletividade. A palavra é uma espécie de ponte lançada entre mim e os outros. Se ela se apoia sobre mim numa extremidade, na outra apoia sobre o meu interlocutor. A palavra é o território comum do locutor e do interlocutor (BAKHTIN, 2003, p.113).

A imagem da palavra como ponte é de extrema relevância para compor a lírica coletiva no rap. Ademais, é complementada pela noção de diálogo inconcluso. O autor aponta ainda que cada fala é parte de um grande diálogo inconcluso: "A única forma adequada de expressão verbal da autêntica vida do homem é o diálogo inconcluso. A vida é dialógica por natureza. Viver significa participar do diálogo: interrogar, ouvir, responder, concordar, etc." (BAKHTIN, 2003, p. 348).

Assim, como viver representa estar em atitude responsiva, visto que não somos seres passivos, pois interrogamos, respondemos, questionamos, concordamos, discordamos etc, nesse sentido, fica mais fácil entender o porquê das atitudes dos rappers quando entram em cena, por exemplo, num palco produzindo e reproduzindo gestos com as mãos, braços e pernas, o corpo como um todo, tudo é expressão dialógica, tudo é intervenção na esfera social, é performance (ZUMTHOR, 2014). Além disso, o rap ao buscar/utilizar a forma dialógica polifônica de enunciação pretende ampliar significativamente o diálogo entre o eu lírico e sua comunidade, ou melhor, as comunidades periféricas já que: "periferia é periferia em qualquer lugar" (RACIONAIS MCs, 1998). De tal modo, a lírica do rap manifesta-se numa situação de interação, procura ver-se manifestando no outro e vice-versa. Desse modo, busca complementar, talvez de senso crítico, aqueles que não conseguem compreender que é só por meio de uma união que alcançarão seus objetivos, isso no sentido em que

\footnotetext{
O excedente de minha visão em relação ao outro indivíduo condiciona certa esfera do meu ativismo exclusivo, isto é, um conjunto daquelas ações internas ou externas que só eu posso praticar em relação ao outro, a quem elas são inacessíveis no lugar que ele ocupa fora de mim; tais ações contemplam o outro justamente naqueles elementos em que ele não pode completar-se (BAKHTIN, 2003, p.323).
}

Desse modo, as relações sociais, históricas e discursivas que se realizam cotidianamente nas diferentes esferas da sociedade, assim como as que acontecem no universo marginalizado da periferia, evidenciam o desejo sócio humano de ser sujeito do discurso e não apenas objeto dele. 
Nos versos de "Fórmula mágica da paz" e "Capítulo 4 versículo 3", canções poéticas integrantes do disco Sobrevivendo no Inferno (2008); e "Negro Drama", do disco Nada Como um Dia Após o Outro Dia (2002); todos dos Racionais MCs, observase os procedimentos dialógicos apontados por Bakhtin, na medida em que contribui também para consolidar o uso de um discurso lírico-coletivo pelo gênero rap:

Essa porra é um campo minado

Quantas vezes eu pensei em me jogar daqui,

Mas, aí, minha área é tudo o que eu tenho

A minha vida é aqui e eu não consigo sair.

É muito fácil fugir mas eu não vou.

Não vou trair quem eu fui, quem eu sou.

Eu gosto de onde eu sou e de onde eu vim,

Ensinamento da favela foi muito bom pra mim.

(RACIONAIS, 1998)

$\mathrm{O}$ trecho explicitamente apresenta o esquema lírico de centralidade no eu. O MC fala de si pra si mesmo, vide grifos. Fala dos dramas, das angústias, das alegrias e ensinamentos que obteve no lugar onde mora, o qual é, ao mesmo tempo, seu "tudo": "minha área é tudo que tenho/ a minha vida é aqui"; e seu "nada": "essa porra é um campo minado / quantas vezes eu pensei em me jogar daqui". Muitas vezes, nessa poesia, o lírico chega ao estágio de autorreflexão, a expressão interior do eu - a primeira voz da poesia - e se faz presente como se pode ver neste outro trecho de "Fórmula mágica da paz":

Choro e correria no saguão do hospital.

Dia das criança, feriado indo pro final.

Sangue e agonia entra pelo corredor.

Ele tá vivo! Pelo amor de Deus doutor!

4 tiros do pescoço pra cima, puta que pariu a chance é mínima!

Aqui fora, revolta e dor, lá dentro estado desesperador!

$\mathrm{Eu}$ percebi quem eu sou realmente, quando eu ouvi o meu subconsciente:

"E aí mano Brown cuzão? Cadê você? Seu mano tá morrendo o que você vai fazer?". Pode crê, eu me senti inútil, eu me senti pequeno, mais um cuzão vingativo, puta desespero.

não dá pra acreditar, que pesadelo, eu quero acordar.

Na parede o sinal da cruz.

Que porra é essa? Que mundo é esse? Onde tá Jesus?

Porra, eu tô confuso. Preciso pensar

Me dá um tempo pra eu raciocinar

Aí fudeu, fudeu, decepção essas hora...

A depressão quer me pegar vou sair fora

(RACIONAIS, 1998) 
No trecho, o gatilho que aciona o estado de angústia do eu lírico é o socorro prestado ao seu amigo baleado. Uma explosão intensa de sentimentos como revolta, dor, inutilidade, vulnerabilidade, impotência etc., o inundam. No limite, o texto toma proporções de uma espécie de monólogo interior, vide grifos. Vê-se configurada aqui a teoria Eliotiana - a voz que fala consigo mesmo. A utilização das aspas dá ênfase ao discurso lírico que centraliza o eu. Ademais, o eu lírico questiona-se e questiona a realidade na qual está inserido. Entra numa espécie de colapso interior em que seus valores e ideologia parecem não fazer mais sentido. Eis aqui um bom exemplo do discurso lírico do rap, leia-se como sendo a primeira voz da poesia, que apresenta uma espécie de centralidade no eu ao passo que busca também falar para/do outro.

No trecho a seguir, em sua construção poética, o eu lírico enuncia uma mensagem de incentivo e perseverança ao seu interlocutor que ora é o outro ora é si mesmo, eis aqui outro exemplo da expressão lírica do rap

$\underline{\text { Voe, }}$ e que todo vento a bem te soe ao descobrir

A natureza da centelha divina que existe em si

Desato o nó da trama, enterro a discórdia no abraço

Arrebato os peito de bronze por trás das barra de aço

$\underline{\text { Se renda, entenda o que ataca, a cegueira amola a faca }}$

Da má lida com a existência, faz a luz da essência opaca

(CRIOLO, 2012)

No poema "Negro Drama", também é possível observar o aspecto de centralidade:

Negro drama,

Cabelo crespo,

A pele escura,

A ferida e a chaga,

A procura da cura,

O drama da cadeia e favela,

Túmulo, sangue,

Sirene, choros e vela,

Negro drama,

Eu sei quem trama,

E quem tá comigo,

O trauma que eu carrego,

Pra não ser mais um preto fudido

(RACIONAIS, 2002) 
Essa estrofe apresenta os versos iniciais de Negro Drama. A centralidade no eu novamente está presente, ainda que, num primeiro momento, possa parecer que os versos estão na terceira pessoa. Com efeito, a estrutura textual da canção é dívida em duas partes, a primeira é enunciada por Edy Rock (integrante vocalista dos Racionais MCs) que apresenta o conflito do jovem negro a partir de uma visão ampla. Ainda que forte e cheia de denúncia, a enunciação desta primeira parte é menos agressiva do que a da segunda parte; está mais próxima da típica enunciação do rap.

Já o fragmento abaixo é o início da segunda parte da canção, agora o enunciador é Mano Brown, que então toma o discurso para si, falando sobre a condição do negro de modo autobiográfico, isto é, usando elementos de sua própria biografia na favela para dar caráter ainda mais denso à centralidade do eu. Eis o trecho:

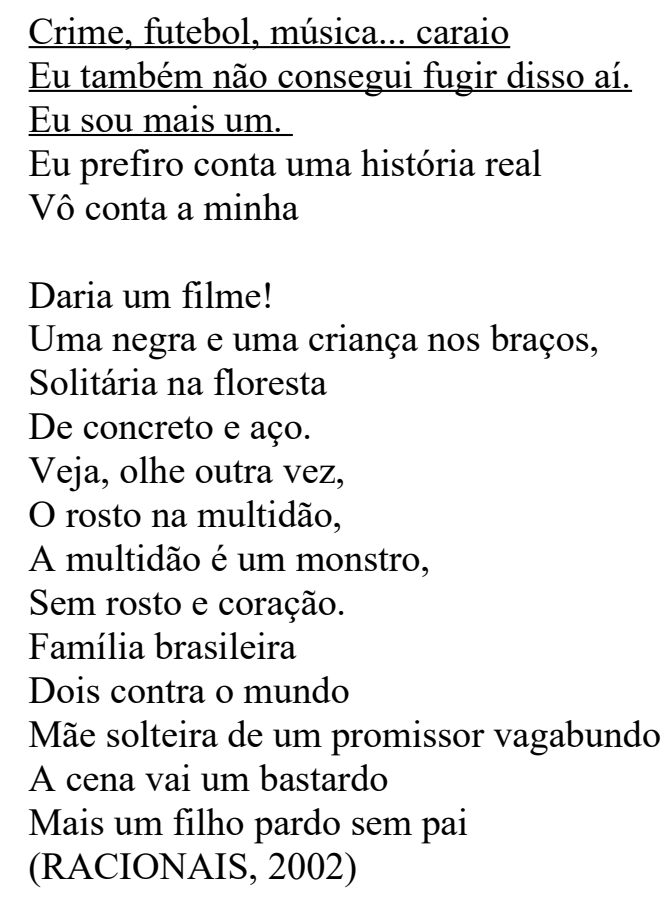

O trecho grifado é apresentado sob a entonação da fala comum, sem a modulação dramática e violenta da voz que caracteriza o rap. A partir da segunda estrofe o relato vai adquirindo um tom mais inflamado, mais cantado, numa crescente retórica cada vez mais agressiva e contundente. Mais para o fim do poema, outros integrantes do grupo cantam também, acompanhando Brown - evidenciando novamente a tensão discursiva, vista acima, entre o eu-individual e o eu-coletivo que se configura no rap. 
Essa característica também pode ser encontrada nos fragmentos abaixo

Eu tenho uma missão e não vou parar

Meu estilo é pesado e faz tremer o chão

Minha palavra vale um tiro e eu tenho muito munição

Talvez eu seja um sádico

Um anjo um mágico

Juiz ou réu

Um bandido do céu

E a profecia se fez como previsto

1997 depois de Cristo

A fúria negra ressuscita outra vez

Racionais capítulo 4, versículo 3

(RACIONAIS,1998)

Novamente a fórmula lírica configurada, um "eu-nós" que se manifesta como uma espécie de enviado que ressurge, autodenominando-se como "A fúria negra" para terminar uma, já iniciada, missão. Possivelmente, os objetivos centrais dessa missão estão pautados na (re)construção de uma imagem positiva do povo negro, o rompimento do histórico ciclo de exclusão social, o combate ao racismo à moda brasileira. Ressaltase que isso é uma marca contundente do caráter coletivo e de comunidade dessa poesia.

Essa marca fica evidente nos versos/estrofes de "Eju ore ndive" (Venha com nós) e koangagua (Nos dias atuais) do grupo Brô Mcs ( $1^{\circ}$ grupo indígena de rap do Brasil)

Ape Che rap ndopai

Aqui meu rap não acabou

Ape Che rap oñembyrü

Aqui meu rap está apenas começando

Che ro henoi e ju ore ndive

Nós te chamamos para revolucionar

Che ro henoi eju ore ndive

Jaha ñande Kuera jaguata

Vamos todos juntos no rolê

Jaha nãnde jarya

Vamos todos nós ser felizes

Jaha já chuka, karaipe ke Che há hae ome é jaiko porá.

Vamos mostrar para o branco que eu e você podemos viver em paz

(BRO MCs, 2009)

Hai amoite ndoikua'ai mbaeve

Korap oguarê amoite tenonde

Apuka penderehe, nde ave reikotevê

Che ñe'e avamba'e oi chendive

Añe'e haetegua ndaikosei ndechagua

Aporahei opaichagua ajuahechuka

Ava mombeuha ava koangagua 
Rap ochechuka upea ha'e tegua

(BRO MCs, 2012)

Certamente o que salta aos olhos são os versos em língua Guarani. Por si só a utilização dessa língua já acentua o caráter de coletividade, de resistência e atuação intelectual de seus produtores, e, ainda marca o seu lugar de fala. A organicidade da poesia do rap indígena também é marcada pela inerente laboração de um discurso líricocoletivo, desde o título escolhido "Eju ere ndeve", em português: Venha com nós. Além disso, há um empenho em conscientizar seus pares, sobretudo os jovens, e resistir às formas de exclusões sócio-política-religiosa-cultural historicamente sofridas pelos povos indígenas por conta dos processos de invasão e colonização de seus territórios, por países europeus, e a implantação da escravidão. Como se sabe, esse contexto histórico de exclusão e escravidão é o mesmo que foi imposto aos negros africanos. Talvez, esse seja o principal fio condutor que gera o sentimento de coletividade e de pertença (Hall, 2003) existente na poesia lírico-coletiva do rap nacional.

Em diálogo com esse contexto, o nordestino (também marcado historicamente pela discriminação e exclusão social) produz o seu rap a partir das características que lhe veste

Rasgo de leste a oeste como peste do sul ao sudeste

Sou rap agreste norte-nordeste epiderme veste

$\underline{\text { Se assumam são clandestinos se negam não nordestinos }}$

Vergonha do que são, produção sem expressão própria

Só frestyleiro em nordeste não querem ser repentistas

Rejeitam xilogravura o cordel que é literatura

Quem não tem cultura jamais vai saber o que é rapadura

Foram nossas mãos que levantaram os concretos os prédios

Os tetos os manifestos, não quero mais intermédios

Escuta! a cidade só existe por que viemos antes

Na dor desses retirantes com suor e sangue imigrante

Sou doce lá dos engenhos e venho com essa doçura

Contenho poesia pura a fartura de rima tenho

Desenho nossa cultura por cima e não por de baixo

(RAPADURA, 2012)

A valorização da cultura popular e da identidade nordestina são as marcas fortes do trecho. Fica evidente o esforço do $\mathrm{MC}$ em promover, num primeiro momento, uma crítica positiva no tocante à sua cultura raiz. Por outro lado, promove também uma ácida crítica aos seus pares que rejeitam suas raízes identitária e cultural, e ainda à discriminação sofrida pelos nordestinos nas grandes urbs brasileiras. Ademais, a ação 
consciente, o ato sociopolítico de valoração da cultura popular nordestina e de rechaço à histórica exclusão sociocultural sofrida por seus pares, construída(o) por Rapadura (atente-se para a nomenclatura que o nomeia, é a junção do acrônimo rap e do substantivo rapadura os quais marcam a simbiose cultural que o MC representa e apresenta em sua poesia) é uma constante nesse tipo de poesia. Isso porque é uma arte produzida por minorias nas periferias, assim sendo, tudo nessa poética torna-se um ato político e, consequentemente, de resistência (DELEUZE e GUATTARI, 1977).

A poesia coletiva do rap nacional permanece negra, indígena, nordestina mestiça -, não raro, se converte e converge em ações de revide e rechaço aos discursos e procedimentos de exclusão. Desse modo pode-se pensar no rap como o gênero (BAKHTIN, 2003) desenvolvido pelos excluídos para se fazer presente, se visibilizar, no embate existente na arena sócio discursiva brasileira. Gênero lírico pelo qual o MC fala diretamente ao leitor/ouvinte, expondo sentimentos, estado de espírito e percepções sociais. Traz consigo, desde sua origem, um inflamado discurso crítico subversivo frente ao discurso dominante, como se viu e se vê nos trechos abaixo:

\author{
Hey, Senhor de engenho \\ Eu sei, bem quem é você \\ Seu jogo é sujo \\ E eu não me encaixo \\ Eu vim da selva sou leão \\ Sou demais pro seu quintal \\ (RACIONAIS,2002) \\ Por que pobre pesa plástico \\ Papel papelão \\ Pelo pingado \\ Pela passagem, \\ Pelo pão, por que? \\ (GOG, 2000)
}

Além disso, demonstra também uma reação de resistência frente ao tipo de consumismo que corrompe os valores pregados e difundidos por seus antecessores:

Em troca de dinheiro e um carro bom

Tem mano que rebola e usa até batom

Seu comercial de tv não me engana

Eu não preciso de status nem fama

Seu carro e sua grana já não me seduz

E nem a sua puta de olhos azuis

Efeito colateral que seu sistema fez 
(RACIONAIS, 1998)

Conscientemente o rap apresenta a condição histórica de seus produtores, o que nesse tipo de poesia é uma das características que (re)afirma sua autenticidade e coletividade:

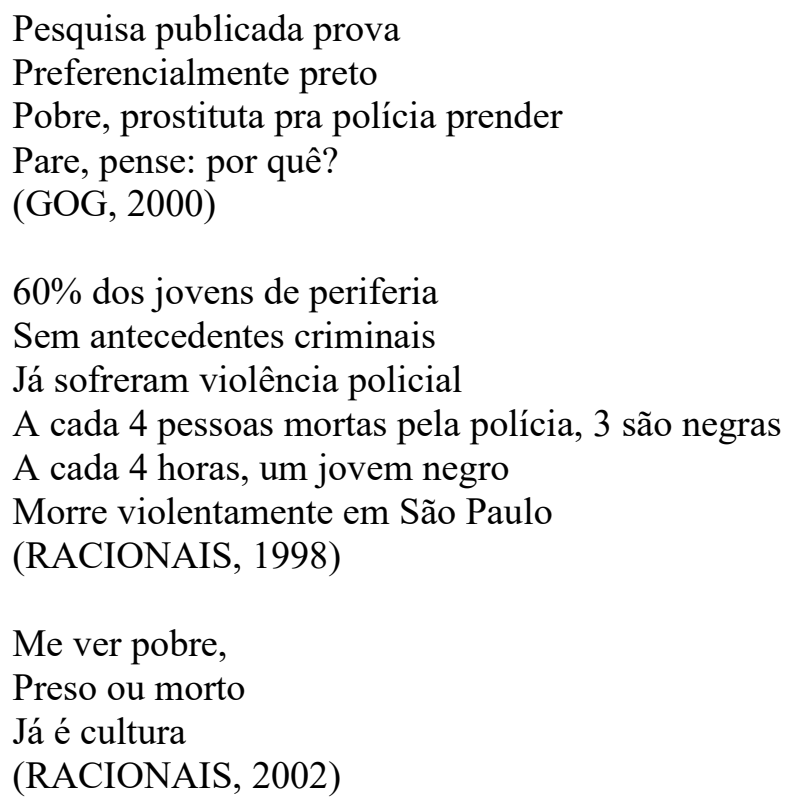

O que se destaca nos trechos é a consciência do eu lírico em relação à sua condição que também é a mesma dos seus pares. Explicita ainda a existência de uma cultura nacional de exclusão de negros, pardos, prostitutas, homossexuais que não raro foram condicionados à pobreza socioeconômica. Em meio a toda essa discussão é preciso que se ressalte que o rap, por meio de seus produtores, manifesta o desejo de ser reconhecido como sendo expressão poética de grupos excluídos socialmente, uma arte negra (des)elitizada. Desse modo, o rap manifesta-se como discurso lírico, crítico e subversivo que prioriza o retrato das vivências de seus próprios produtores e de suas comunidades, na medida em que faz isso explicita características linguísticas, modos de utilização da fala e da escrita e os aspectos socioculturais que constituem a singular identidade desse discurso intrinsecamente ligado ao popular.

Nesse sentido a constituição do texto, nas letras do rap, se caracteriza, sobretudo pela forma coloquial de utilização da linguagem falada e escrita. Em outras palavras carrega consigo desde sua gene, as marcas da oralidade. Os versos abaixo são 
emblemáticos para confirmação das marcas da oralidade na escrita (isso no rap é intencional, pois funciona como espécie de ponte entre o MC e seu "irmão")

\author{
O que é o que é? \\ Clara e salgada, \\ Cabe em um olho \\ E pesa uma tonelada \\ Tem sabo de mar, \\ Ó, vou te fala \\ Tô chapando \\ Eita, mundo bom de acaba! \\ Epa, pera lá! Muita calma, ladrão \\ Cadê o espírito imortal do Capão? \\ Diz que homem não chora, ha, tá bom, falou \\ Não vai pra grunp irmão, aí, Jesus chorou! \\ [...] Aí! Dorme, hein, doidão! Mil fita acontecendo e cê aí? \\ A fita é o seguinte, ó \\ Não é esqueirando não, ó \\ Fita de mil grau. \\ Onte eu tava ali de $\mathrm{Cb}$, no pião \\ Com um truta firmezão \\ Cê tem que conhecer \\ Se pã, cê liga ele \\ Vai saber, de repente \\ Ele fazia até um rap num passado recente. \\ (RACIONAIS, 2002)
}

Nesse fragmento pode ser visto uma referência ao mundo das tradições orais das 'adivinhas' de o que é o que é? Vide grifo. Em seguida, são apresentados sentimentos conflitantes, por meio da metáfora que utilizam o esquema: lágrima versus vento. Esses elementos se misturam e se confunde, a lágrima pode ser entendida como sendo a manifestação externo-concreto do mundo interno-abstrato do eu lírico. No mundo conflituoso do eu lírico a lágrima representa e simboliza, ao mesmo tempo, fraqueza e força, derrota e vitória. É sabido que verter lágrimas está na tensão entre a tristeza e a alegria, o eu lírico traz a imagem de Cristo, que segundo a narrativa bíblica chorou antes de sua morte, para, talvez, "atestar" que chorar é um sentimento nobre e humano.

As marcas da oralidade ajudam a construir o ambiente/cenário da ação e a identidade sociocultural dos personagens, vide grifos. Essa ambientação linguística se faz necessária no sentido em que o $\mathrm{MC}$ se esforça para transmitir sua mensagem, em geral, para um interlocutor, que assim como ele, não partilha da norma culta da língua falada/escrita. Esse não domínio da norma culta da língua, pelos sujeitos periféricos, ainda é visto por muito setores elitizados da sociedade como marca principal da 
ignorância e inferioridade intelectual desses sujeitos. No entanto, frisa-se aqui que isso é o modus operandi do rap. É uma estratégia para uma maior veiculação e apropriação da mensagem pelos receptores e também uma característica, talvez a mais central no rap, identitária do sujeito-emissor que explicita e (re)afirma o seu lugar de fala, seu lócus de enunciação. Esse é um fator que está diretamente ligado ao caráter coletivo que vinculase na poesia do rap.

Além das marcas da oralidade, o rap apresenta outras características, a análise segue, agora, com "Negro Drama", também dos Racionais e "Brasil com P", de GOG, respectivamente:

\author{
Negro drama, \\ Eu sei quem trama, \\ E quem tá comigo, \\ O trauma que eu carrego, \\ Pra não ser mais um preto fudido \\ (RACIONAIS MCs, 2002) \\ Pedro Paulo \\ Profissão pedreiro \\ Passatempo predileto, pandeiro \\ Pandeiro parceiro \\ Preso portando pó \\ Passou pelos piores pesadelos \\ Presídios, porões \\ Problemas pessoais, psicológicos \\ Perdeu parceiros passado presente \\ Pais parentes principais pertences \\ (GOG, 2000)
}

$\mathrm{O}$ que se destaca de imediato nas estrofes são as figuras de linguagem, principalmente as aliterações, as rimas e os versos livres, isso para ficar em alguns exemplos. Aliteração é uma das figuras de linguagem largamente utilizada em poesia, que consiste em repetir fonemas num verso ou numa frase, especialmente as sílabas tônicas de forma a obter um efeito expressivo. Esta figura ajuda a criar uma musicalidade que valoriza o texto literário. Mas não se trata de simples sonoridades destituídas de conteúdo. Geralmente, a aliteração sublinha (ou introduz) determinados valores expressivos. A musicalidade também se manifesta nos trechos e é entendida aqui como sendo a esfera da rima dentro do processo de criação do rap. Como se vê, os fragmentos (apresentados acima) manifestam diversos aspectos literários os quais atestam o teor poético dessa produção contemporânea da cultura popular. 
As análises atestam que a poesia do rap se manifesta por meio do discurso que embora focado no eu, visa falar ao outro, à coletividade. Com isso mira também consolidar seu lócus de enunciação, seu local de fala que se configura a partir da periferia rumo ao centro. Nesse sentido, pode-se dizer que a voz que ecoa do rap assim como a da literatura periférica não é focada num "eu-individual", numa voz isolada, numa única voz, pelo contrário, está sempre focada num “eu-nós”. Sendo assim, não é um equívoco pensar o rap como sendo uma espécie de manifesto da periferia, o qual é construído, sobretudo, a partir da crença no poder da palavra escrita-cantada como forma de demonstrar pertencimento a uma comunidade e de libertação do indivíduo oprimido.

\section{Considerações sobre poesia e resistência}

Como se sabe tradicionalmente a compreensão de literatura está atrelada exclusivamente à lida artística com a palavra escrita em decorrência da sedimentação e valorização da cultura escrita, em detrimento das orais/ágrafas, nos países ocidentais. Entretanto, a partir da segunda metade do século XX tal compreensão, sobretudo no tocante a poesia, vem, à revelia dos puristas, se pluralizando em suas formas, gêneros e plataformas de veiculação (no decorrer do texto ver-se-á que a estética lírica do rap é uma prova disso).

$\mathrm{Na}$ medida em que a poesia incorpora novos signos, sons, linguagens e se manifesta em múltiplas plataformas midiáticas, ao passo que está sendo reivindicada e produzida com mais intensidade por atores sociais historicamente cerceados desse poder (negros, indígenas, mulheres, LGBTs, entre outros) em lócus de enunciação localizados a margem do cânone - nas periferias -, é capaz de oferecer um panorama completo e mais profundo do que é a cultura contemporânea e sua diluição das fronteiras culturais.

Pensando no Brasil, é possível entrever que a poesia, sobretudo a de cunho sociopolítico, colaborou e ainda colabora, e muito, para a compreensão do cenário sociocultural do país, isso no sentido em que denuncia as mazelas sociais, os procedimentos de exclusão, e retrata as lutas de classe, o revide e resistência secular à violência sofrida por minorias. Essa poesia entremeou a lacunas sociais e alcançou a esfera nacional na medida em que se atrelou a gêneros populares tais como a canção popular, o samba, o rap (CYNTRAO, 2009; 2015). Entende-se aqui que esses gêneros, 
ou melhor, seus discursos-estéticos reformulam os processos de abordagem, análise e compressão da esfera sociocultural e da realidade brasileira, justamente porque se tem agora o olhar do outro, do periférico.

Isso considerado, o que se lê a seguir são reflexões desenvolvidas no intuito de pensar o rap como um viés dessa pluralização contemporânea. Mais especificamente, levanta a hipótese de que: embora lírica a poesia do rap nacional apresenta um caráter coletivo, periférico e de resistência em sua composição. Afirma-se isso, na medida em que é possível entrever uma espécie de transição do eu lírico do rap, que a priori é um eu-individual, para um eu- nós, essencialmente coletivo; e é nesse empenho de buscar comunidade que reside o seu caráter de resistência. Isso também firma um lócus de enunciação que tem na periferia o seu próprio centro, referenciando assim a ideia de comunidade. Para tanto, buscar-se-á, analisar algumas canções poéticas do rap utilizando instrumentos teóricos da ciência linguístico-literária e do pensamento crítico pautando um debate entre os conceitos correntes de poesia, o corpus teórico escolhido e a lírica do rap, com objetivo de confirmar se tal hipótese é sustentável.

Do ponto de vista técnico/denotativo, sobre poesia diz o dicionário Houaiss (2004, p. 578): "gênero literário (lírico ou dramático) em forma de versos /a arte de compor e escrever em versos”. Já o Dicionário da Língua Portuguesa (2001, p. 638) aponta que poesia: "é a arte de comunicar imagens, sentimentos e ideias por meio de uma linguagem em que sons e ritmos se combinam com os significados". Como se vê, o primeiro dicionário afirma que o que é escrito em verso sob um viés lírico ou dramático é poesia. Enquanto que o segundo refere-se à poesia como sendo algo que vai além daquilo que é composto em verso. Aponta que há toda uma gama de procedimentos cujo intuito principal é, por meio de imagens, comunicar sentimentos, ideias, estado de espírito, o eu, o outro, o espaço, o mundo.

Partindo desses pressupostos é possível entrever, com mais facilidade, no rap seu caráter poético, já que este é um gênero escrito prioritariamente em versos e estrofes e, entre outras, comunicar e informar também são características e objetivos deste gênero. Contudo, esse argumento ainda não é suficiente e também não responde satisfatoriamente o questionamento norteador desse texto, por isso se faz necessário imergir uma vez mais no universo sem fim da poesia.

Entende-se como discurso lírico sendo aquele que, recorrendo a um discurso denso, expressivo e com musicalidade e ritmo, permite artisticamente exprimir as 
emoções, os sentimentos, os desejos ou os pensamentos íntimos que nascem ou se apresentam ao "espírito", ou seja, ao mundo interior do "eu" numa espécie de autorreflexão que pode se manifestar de forma interna ou externa seguindo a seguinte fórmula: um eu que pode ter como interlocutor ele mesmo ou um segundo individuo, sempre apresentando um discurso centralizado no eu e em suas experiências.

Nesse sentido, a poesia será compreendida aqui como sendo "um campo de manifestações muito mais amplo que o que se revelou, a partir do século XVIII, por poema" (FERNANDES, 2003, p. 19). Na visão desse autor o rap mantém uma forte ligação com a tradição da poesia oral: "a poesia oral, no caso o rap, deve ser compreendida em seu contexto de produção, pois é nesse contexto que a voz coletiva se faz presente", afirma ainda que "a poesia oral e a escrita encontram-se num eixo comum que é o próprio significado de poesia" (p. 20). Além de lançar luz sobre a questão da oralidade existente no rap, Fernandes aponta também para a questão da voz coletiva que se faz presente no discurso do rap (viés que se liga diretamente ao objetivo central deste texto) essa questão no intuito de entrever a simbiose do eu lírico que se manifesta nas letras poéticas do rap tendo foco na primeira pessoa do singular (eu) mas que ideologicamente representa a primeira do plural (nós).

Alfredo Bosi aponta, em O ser e o tempo da poesia (1977), a existência de um viés poético de resistência e subversão envolto à poesia frente aos discursos dominantes:

\begin{abstract}
A poesia há muito que não consegue integrar-se, feliz, nos discursos correntes da sociedade. A resistência também cresceu junto com a "má positividade" do sistema Daí vêm as saídas difíceis: o símbolo fechado, o canto oposto à língua da tribo, antes brado ou sussurro que discurso pleno, a palavra-esgar, a autodesarticulação, o silêncio. $\mathrm{O}$ canto deve ser um grito de alarme [...] produção de sentido contraideológico válida para muitos, uma forma de resistência simbólica aos discursos dominantes. A resistência tem muitas faces. Ora propõe a recuperação do sentido comunitário perdido (poesia mítica); ora a melodia dos afetos em plena defensiva (lirismo de confissão); ora a crítica direta ou velada da desordem estabelecida (vertente da sátira, da paródia, do epos revolucionário, da utopia) (BOSI, 1977, p.142).
\end{abstract}

No trecho Bosi aponta que a poesia moderna nasce com algo que incomoda a ordem sócio ideológica vigente (leia-se status quo), a resistência. Ressalta ainda que por isso a poesia figura, na modernidade, à margem da literatura em prosa (o canto oposto à língua da tribo). Pontua ainda que a poesia deve ser o alarde, a arte que destoa e desequilibra o ambiente pacífico da hipocrisia social. 
Dialogando com essas ponderações, entende-se aqui que o rap encaixa-se nesse viés de poesia oral e de resistência apontada por Fernandes e Bosi, respectivamente. Isso na medida em que faz uso da mítica, da confissão e da sátira para compor sua visão do mundo social. Nesse sentido, sua lírica manifesta-se como avesso e contraponto à ideologia dominante. Ademais, carrega em sua lírica as marcas da diáspora negra, da miscigenação étnico-cultural, da oralidade e da cultura popular brasileira e ainda o caráter coletivo de comunidade. Posiciona-se ao avesso da ideologia dominante, desse modo não será equívoco compreende-lo como poesia dos excluídos, o verso da favela. Ademais, a poesia do rap não advém e nem é produto do mundo acadêmico letrado. Tampouco, das grandes bibliotecas nacionais onde, não raro, a entrada é balizada pela pompa estética de seus usuários. Não se liga à poesia normativa dos grandes salões da aristocracia nacional, local onde reina e se tem como única a cultura do erudito. Pelo contrário, a poesia do rap é justamente o seu avesso. É produto do mundo semialfabetizado, do ensino fundamental incompleto, com raríssimas exceções. Não permeia as prateleiras das grandes bibliotecas nacionais, muito menos os debates nos grandes salões. Cultura popular que se manifesta negra, mestiça e diaspórica. Não, não é aquela p. É o poema sujo, imundo, satílírico. A manifestação do protesto congregado na cor e permeada pela dor. Lírica profundamente marcada pelo açoite do chicote; entretanto, abalizada pelo revide a ele, sobretudo.

Por tudo isso é, sem dúvida, um discurso artístico com função de estimular o rompimento de pré-conceitos que habitam o imaginário coletivo nacional - mito da democracia racial, conformismo, inferioridade, cordialidade - e ainda irromper as barreiras de repressão social, política e religiosa. Forma lírico-coletiva autêntica, coletiva, identitária, de resistência e conscientização e de preservação da Cultura Afrobrasileira e da cultura popular como um todo.

\section{Periferia: espaço de resistência e coletividade}

As discussões que se seguirão aqui não têm pretensão de se alocar no espaço do discurso sociológico e/ou geográfico, frisa-se. Contudo, considera que ao promover uma reflexão sobre a poesia do rap faz-se necessário, para uma compreensão mais profunda de seus aspectos e temas, notar as características do espaço geográfico e social em que esta é produzida. Isso porque, nesse tipo de poesia, em geral, o que se escreve reflete 
diretamente o espaço sócio geográfico em que está imerso o eu lírico, logo, liga-se intrinsecamente com as experiências vividas e vivenciadas por seus produtores - os MCs. Nesse sentido, mapear de qual lugar e como é o espaço de onde emerge essa poesia é crucial para se compreender seu viés coletivo, periférico, de resistência, temático e discursivo.

Além disso, caso o argumento acima não baste, há este outro: considerar os elementos extraliterários possibilita, sobretudo, no caso das literaturas produzidas na/pela periferia compreender além dos elementos que as compõem, a dimensão dos efeitos causados pela exclusão secular das comunidades de onde se originam seus produtores. Em outras palavras, é preciso ressaltar que o fazer artístico requer "tempo livre" e que tempo livre requer condições orgânicas (alimento e saúde) e de infraestrutura minimamente favoráveis à possibilidade de criação artística. No entanto, as reivindicações que vêm sendo feitas pelos grupos socialmente minorizados como os de mulheres, negros, indígenas, LGBTs, entre tantos outros, não se dá no âmbito da igualdade da criatividade, e sim no âmbito da igualdade de oportunidades, é disso que se trata. Ademais, apartar o fazer artístico de seu lócus sócio geográfico de criação e enunciação é, a priori, desconsiderar, negar, descartar sua condição de sujeito sócio histórico situado no tempo e no espaço.

Entendendo isso sob a ótica de Milton Santos ao afirmar que

o espaço se define como um conjunto de formas representativas de relações sociais do passado e do presente e por uma estrutura representada por relações sociais que se manifestam através de processos e funções [...]O espaço é um verdadeiro campo de forças cuja formação é desigual. Eis a razão pela qual a evolução espacial não se apresenta de igual forma em todos os lugares [...] $\mathrm{O}$ espaço por suas características e por seu funcionamento, pelo que ele oferece a alguns e recusa a outros, pela seleção de localização feita entre as atividades e entre os homens, é o resultado de uma práxis coletiva que reproduz as relações sociais (SANTOS, 1978, p.122-71).

Desse modo o conceito de espaço é compreendido centralmente como um conjunto de formas representativas de relações sociais do passado e do presente e por uma estrutura representada por relações que estão acontecendo e manifestam-se através de processos e funções que se ligam ao modo de vida estabelecida pelos grupos sociais. Considerando isso e pensando especificamente sobre as características sócio históricas que distingue esse espaço urbano chamado periferia, o que se tem de evidência imediata 
é que tal espaço é marcado pela não infraestrutura, não presença Estado e pela aglomeração da parcela mais pobre da sociedade que não raro são negros, mestiços, caboclos nordestinos, indígenas, em geral. No caso dos indígenas muda-se a nomenclatura de periferia/favela para reserva indígena. Na prática sabe-se que grande parte das reservas, hoje, estão na condição de periferia das periferias. Frisa-se que essas periferias são os podres frutos e prova maior do apartheid étnico-social instalada no país, herança direta dos quase quatro séculos de escravidão. Em contraponto a essa condição segregadora, os sujeitos oriundos desse espaço periférico se unem por meio do imbricamento de suas produções artístico-culturais com objetivo central de constituir e consolidar uma identidade coletiva, própria das minorias uma espécie de sentimento de pertença (HALL, 2003). Nesse sentido, contemporaneamente, a poesia do rap atua fortemente para essa consolidação (uma identidade coletiva) na medida em que se coloca a refletir e ser reflexo do espaço de que é fruto legítimo e também das relações sócio humanas que surgem daí.

Dito isto, propõem-se agora, a partir da poesia lírico-coletiva do rap, entrever as características que configuram o espaço periferia/favela na esfera simbólico e social, e, também a importância dela para os MCs. Isso porque a periferia é o mundo em que os MCs, produtores do rap, estão inseridos e por isso ela

\begin{abstract}
torna-se o principal cenário para toda a produção do discurso do rap. Todas as dificuldades enfrentadas por estes jovens são colocadas no rap, encaradas de forma crítica, denunciando a violência - policial ou não - o tráfico de drogas, a deficiência dos serviços públicos, a falta de espaços para a prática de esportes ou de lazer e o desemprego. Em meio a esse conjunto de denúncia e protesto, ganha destaque o tema do preconceito social e, principalmente, o racial. [...] E, pelo fato de os membros dos grupos serem em grande maioria afrodescendentes, $\mathrm{o}$ enfoque étnico-social ocupa um espaço central no discurso produzido. Ao primeiro momento de denúncia e revolta, segue-se um posterior reforço positivo da autoestima e afirmação da negritude com resgates culturais importantes (TELLA, 1999, p. 60).
\end{abstract}

É preciso compreender que o conceito de periferia é muito mais amplo que a do imaginário social de senso comum. Pois além das periferias/favelas situadas nos morros cariocas, as reservas indígenas, as aglomerações em palafitas ribeirinhas e caiçaras, guetos e cortiços em geral, devem ser consideradas na composição de tal conceito. Sobre suas periferias, o rap, como crônica poética, fornece uma retrato crítico sobre 
como é (sobre)viver neste espaço sócio geográfico marginalizado. Eis a representação da periferia/favela feita pelos sujeitos (MCs) oriundos dela

Periferia é periferia, vários botecos abertos, várias escolas vazias Periferia é periferia, e a maioria por aqui se parece comigo Periferia é periferia, mães chorando, irmãos se matando, até quando? Periferia é periferia em qualquer lugar, gente pobre (RACIONAIS, 2002)

Milhares de olhares imploram socorro na esquina No morro a fila anda a caminho da guilhotina Várias queima de arquivo diária com a fome E vão amontuando os corpo de quem não tem sobrenome Eu nasci junto a pobreza que enriquece o enredo Eu cresci onde os muleque vira homem mais cedo (EMICIDA, 2010)

Observe que a consciência do eu lírico salta aos olhos. Os grifos ajudam na compreensão do espaço físico, ou seja, lugar de muita miséria e pouca diversão, subhumano. Lugar onde crianças são levadas a se transformarem mais cedo em adultos (metáfora da aquisição de responsabilidades que não competem a uma criança e sim a um ser humano maduro em seus aspectos físicos, biológicos e intelectuais), nesse sentido, o indivíduo é visivelmente influenciador e influenciado do/pelo espaço e pelas relações sociais que surgem daí. Isso pode ser entrevisto também nos trechos a seguir

Vida loka cabulosa

$\underline{\text { O cheiro é de pólvora }}$

E eu prefiro rosas

E eu que sempre quis um lugar

Gramado e limpo, assim, verde como o mar

Cercas brancas, uma seringueira com balança

Disbicando pipa, cercado de criança

How, how Brown

Acorda sangue bom

Aqui é Capão Redondo, truta

Não Pokemón

Zona sul é o invés, é stress concentrado

Um coração ferido, por metro quadrado

Quanto, mais tempo eu vou resistir

Pior que eu já vi meu lado bom na U.T.I

(RACIONAIS, 2002)

Essa porra é um campo minado.

Quantas vezes eu pensei em me jogar daqui,

Mas aí, minha área é tudo o que eu tenho.

A minha vida é aqui, eu não consigo sair. 
É muito fácil fugir mas eu não vou.

Não vou trair quem eu fui, quem eu sou.

Eu gosto de onde eu vou e de onde eu vim,

Ensinamento da favela foi muito bom pra mim.

(RACIONAIS, 1998)

Evidencia-se aqui a periferia como espaço de relações turbulentas entre o eu lírico e si mesmo e o outro. Explicita a dicotomia do ideal versus o real. Desse modo, a poesia do rap parece ser, dialeticamente, um movimento que ao usar expressões tão típicas do seu meio, "transgride e rompe com as barreiras de vedação do discurso" (FOUCAULT, 1996, p.10). Esses "cronistas" ao narrarem suas próprias histórias buscam representa-las de modo realista, por meio da verossimilhança, pois os temas de seus poemas estão consubstanciados em sua própria vivência, o mundo da periferia, assim seu relato ganha uma maior autenticidade, como se vê na citação acima.

É na periferia que grande parte da produção artística popular contemporânea tem sido criada. Desse modo ao tocar de modo profundo e consciente sobre questões socioculturais de exclusão, violência e ausência do Estado, o rap se configura como uma poesia coletiva, embora lírica. Ressalta-se que tudo no rap é consciente, é contextualizado. O produtor do rap é constituído de uma consciência social, política e histórica, em geral, acima da média, e por isso consegue analisar e promover reflexões extremamente relevantes sobre como se dá as relações entre a camada social em que está inserido e as outras que compõem a esfera social brasileira. Essa consciência se dá na busca pelo reconhecimento artístico e inserção na esfera dos bens simbólicos e culturais, nesse caso especificamente da literatura. Nessa esteira de pensamento, Alves propõe uma pertinente reflexão a respeito da tensão existente na esfera literária brasileira contemporânea

A produção literária de autores e autoras negros vive verdadeiros sacos de varas. Primeiro é acusada de essencialismo, depois é punida com o anonimato. Trata-se de um anonimato complexo, que retira a legitimidade do negro como escritor. A esse escritor é reservado um lugar de objeto de estudos no discurso de pesquisadores, ou seja, alguém que só tem existência através do agenciamento do outro. Em última análise, reduz-se a capacidade de um trabalho de criação literária. Nesse saco de sutilezas, além de uma manifestação de perplexidade, pode-se traduzir: como é que o negro se atreve a ser escritor, agenciando as interioridades de um "devir negro"? $\mathrm{Na}$ verdade, existe a prática de defender o status quo da literatura e a visão de que é um lugar reservado a determinados assuntos, específicos das suas formas de abordagem. Autodenominar-se escritor 
de literatura negra é embrenhar-se nessa selva de significados, relações e inter-relações, procurando uma outra forma de expressão literária. A existência de uma literatura específica se dá através de um conjunto de significados e intenções, símbolos, estéticas e a tradução em arte dessa visão do mundo. Assim, o termo "negro" não designa, aqui, a cor epidérmica de alguém. Antes de tudo, era um termo pejorativo, utilizado na escravidão para diminuir e inferiorizar. [...] Ao inverter-se a intenção negativa do termo, a literatura negra obriga-se também a inverter o olhar sobre o brasileiro negro, tirando-lhe a máscara da invisibilidade e dando existência ao que se considera massa amorfa, sem rosto, sem sentimento, interioridade e humanidade (ALVES, 2012, p. 235).

Complemente-se que a constatação dessa tensão estende-se ao fazer artístico, sobretudo literário, de outras minorias sociais como, por exemplo, a indígena e a LGTBs. É nesse cenário que a poesia lírica do rap constrói sua ideologia coletiva na esfera sociocultura. Faz isso a partir do seu lugar de fala, de seu lócus de enunciação - a periferia.

Ressalta-se que esse lugar de fala (a esfera literária) historicamente é negado a essas minorias. Nesse sentido, foram ao longo da história literária brasileira (tanto na prosa quanto na poesia) representadas de forma quando não caricatural, exótica, como afirma Dalcastagné

Desde os tempos em que era entendida como instrumento de afirmação da identidade nacional até agora, quando diferentes grupos sociais procuram se apropriar de seus recursos, a literatura brasileira é um território contestado. Muito além de estilos ou escolhas repertoriais, o que está em jogo é a possibilidade de dizer sobre si e sobre o mundo, de se fazer visível dentro dele [...] Daí os ruídos e desconforto causados pela presença de novas vozes, vozes não autorizadas (DALCASTAGNÉ, 2012, p. 07).

A ponderação da autora vem ao encontro das reflexões que estão sendo sustentadas nesse texto, no sentido em que entende e entreve a poesia do rap como sendo uma dessas vozes não autorizadas, que à revelia do sistema social e do cânone literário nacional, se mantém no embate da busca pelo poder de falar de si e dos seus. Isso se materializa no sentido em que o $\mathrm{MC}$, por meio de sua poesia, torna público sua origem identitária, frustrações, angústias, derrotas, vitórias e glórias. Nisso ativa em seus pares o instinto de empatia, resiliência e proteção mútua - a dimensão coletiva -, já que a periferia os une "pela dor, pela cor e pelo amor". 
A poesia lírico-coletiva do rap revela o Brasil que não aparece nos anúncios de pacotes de viagem, nem nos comerciais de TV sobre suas belezas. Ao contrário, explicita o quanto violento é o cotidiano vivido pela grande maioria do povo, expõe sem tarja o rosto, a cor e camada social de quem morrem e de quem mata nesse país, denuncia ainda a hipocrisia social que nega o racismo e exclusão social existente. E é certamente por isso que tal poesia (estenda-se isso também para prosa, música, religião, etc.) continua sendo asfixiada.

\section{CONSIDERAÇÕES FINAIS}

Nessas reflexões descortinou-se a existência de uma centralidade no eu, ou seja, o rap, em termos gerais, tem o discurso centrado na figura do enunciador - o $\mathrm{MC}-$ no entanto, esse mesmo discurso individual busca configurar o "nós" - uma dimensão coletiva. Isso se dá devido ao foco temático-discursivo estar pautado nas próprias vivências/experiências do enunciador em seu lócus de enunciação. Além do mais, por meio de suas imagens poéticas, expõe o contraste entre os modos de vida de sua comunidade, historicamente excluída, mas também produtora de arte e cultura, um espaço comum a muitos outros que se identificam e se veem retratados nesse discurso.

Constatou-se ainda que o rap mantém uma crença no poder de transformação social por meio da palavra, do discurso engajado. É, sem dúvida, a tentativa de rechaçar a exclusão e toda e qualquer forma de violência física, social e racial. Ademais, esse discurso é consciente, marcado pela subversão, rebeldia, transgressão e insubordinação à opressão do status quo. É assinalada também, por uma autoafirmação manifestada numa expressão própria, uma linguagem própria que reflete um modo periférico, negro, mestiço e coletivo de se (re)pensar e (re)agir na esfera sociocultura brasileira.

Além disso, a coletividade é uma característica que permeia todas as obras artísticas produzidas pelas periferias. Essa coletividade em vários momentos de atuação na esfera social configura-se em atitudes de cunho sociopolítico representativo. Não raro, tais atitudes tomadas no combate à herança escravista de quase quatro séculos de escravidão, cujo racismo e desigualdade social são as faces mais desumanas. 
Desse modo, lança um 'novo' olhar sobre o social, agora sob a ótica do artista periférico. Por meio de sua poética visa abarcar sua comunidade, ainda que falando propriamente de si, compondo assim na esfera de sua lírica um forte viés de coletividade/comunidade. Isso, pensado criticamente, marca um momento de transformação, ampliação e enriquecimento do campo literário brasileiro. Certamente é algo benéfico, ainda que muitos se queiram cegos e mudos a isso.

Assim, continuar impedindo, barrando, cerceando essa(s) manifestação(ões) de dizer o que ela(s) tem pra dizer e de chegar onde ela pode chegar é simplesmente escamotear a outra face da cultura e suas relações sociais. Desse modo, a leitura do cenário sociocultural se dá incompleta o que leva a uma leitura também incompleta da nação. Como já bem ponderou Conceição Evaristo "Se não lemos todos os passos criativos da nação, estamos lendo uma nação em pedaços, estamos lendo uma nação incompleta". Nesse sentido, cabe a poesia divergente do rap expor justamente o lado invisibilizado da cultura brasileira personificada nos versos de Nelson Maca - "Sou poeta/ E como poeta posso ser razão divergente/ E como razão divergente/ Posso levantar ainda hoje meu quilombo de palavras".

\section{REFERÊNCIAS}

ALVES, Miriam. Cadernos Negros (n. 1): estado de alerta no fogo cruzado. In: Poéticas afro-brasileiras. 2. ed. Belo Horizonte: Mazza Edições, 2012, p. 221-240.

BAKHTIN, Mikhail. Estética da Criação Verbal. Trad. Paulo Bezerra. 4. ed. São Paulo: Martins Fontes, 2003.

BOSI, Alfredo. O ser e o tempo da poesia. São Paulo: Cultrix, 1977.

BOSI, Alfredo. Literatura e resistência. São Paulo: Companhia das Letras, 2002.

BOSI, Alfredo. Leitura de Poesia. São Paulo: Companhia das Letras, 2003.

BRO MCs. Rap indígena. Independente, 2009.

BRO MCs. Koangagua. Independente. 2012.

CAMARGOS, Roberto. Rap e política: percepções da vida social brasileira. São Paulo: Boitempo, 2015.

CYNTRAO, Sylvia Helena. Cultura contemporânea: a redefinição do lugar da poesia.

In. Poesia: o lugar do contemporâneo. Brasília: UnB, 2009.

CYNTRAO, Sylvia Helena. Mão e contra Mão em Chico Buarque. In. Chico Buarque sinal aberto! Rio de Janeiro:7letras, 2015.

CRIOLO. Convoque seu Buda. Oloko Records, 2014.

DELEUZE, Gilles e GUATTARI, Felix. Kafka: por uma literatura menor. Rio de Janeiro: Imago Editora, 1977.

DALCASTAGNÉ. Regina. Literatura brasileira contemporânea: um território contestado. Vinhedo: Horizonte, 2012. 
ELIOT, T. S. As três vozes da poesia. In: A essência da poesia. Tradução de Maria Luiza Nogueira. Rio de Janeiro: Artenova, 1972.

EMICIDA. Pra quem já Mordeu um Cachorro por Comida, até que eu Cheguei Longe. Laboratório Fantasma, 2010.

FERNANDES, Frederico Augusto Garcia. A voz em performance. Tese Doutorado. Unesp: Assis, 2003.

FOUCAULT, Michel. A Ordem do Discurso. São Paulo: Loyola, 2010.

GARCIA, Walter. A alegria melancólica de João Gilberto, a agressividade lúcida do Racionais MCs: canção popular e experiência social no Brasil. In: Palavra cantada. Rio de Janeiro:Uduerj, 2014.

GOG. CPI da favela. Trama, 2000.

GOG. Aviso às gerações. Trama, 2006.

GONÇALVES, Genival, Oliveira; MACA, Nelson. Rima denuncia. São Paulo. Global, 2010.

HALL, Stuart. A identidade Cultural na pós-modernidade. $2^{\circ}$ ed. Rio de Janeiro: DP\&A, 1998.

HALL, Stuart. Da Diáspora: identidades e mediações culturais. Trad. Adelaide Resende Belo horizonte: UFMG, Brasília: Rep. UNESCO no Brasil, 2003.

HOUAISS, Antonio. Dicionário de língua portuguesa. Rio de Janeiro: Objetiva, 2004. MACA, Nelson. Gramática da ira. Salvador: Blackitude, 2015.

OLIVEIRA, Cleber José de. Rap: o discurso subversivo do intelectual marginal.

Dissertação de Mestrado, UFGD. 2012, p. 121. Disponível em:

$<$ https://www.ufgd.edu.br/pos-graduacao/mestrado-letras/dissertacoes $>$ Acesso em: 18 abr. 2017.

RAPADURA, Xique-chico. Fita Embolada do Engenho - Rapadura na Boca do Povo, 2012.

PAZ, Octavio. O arco e a Lira. Rio de Janeiro: Nova Fronteira, 1982.

RACIONAIS MCs. Sobrevivendo no Inferno. Cosa Nostra, 1998.

RACIONAIS MCs. Nada melhor que um dia após o outro. Cosa Nostra, 2002.

SALLES, Écio. Poesia revoltada. Rio de Janeiro: Aeroplano, 2007.

SANTOS, Milton. Por uma Geografia Nova. São Paulo: Hucitec, Edusp, 1978.

SANTOS, Milton. Espaço e Sociedade. Petrópolis: Vozes, 1979.

VAZ, Sérgio. Manifesto da Antropofagia Periférica. In: Revista Literatura Marginal. São Paulo, 2010.

TELLA, Marco Aurélio Paz. Rap, memória e identidade. In: ADRADE, Elaine Nunes de. (Org.). Rap e educação Rap é educação. São Paulo: Summus, 1999.

XIMENES, Sergio. Dicionário da língua portuguesa. São Paulo: Ediouro, 2001.

ZUMTHOR, Paul. Performance, recepção, leitura. Tradução de Jerusa Pires Ferreira e Suely Fenerich. São Paulo: Cosac Naify, 2014. 